\title{
Effect Of Art Education In Teaching The Concept Of Tissue To Autistic Children ${ }^{1}$
}

\author{
Serap Buyurgan \\ Gazi University, Ankara \\ serapb@gazi.edu.tr
}

\author{
Başak Danacı Polat \\ Gazi University, Ankara \\ basakd8@gmail.com
}

\begin{abstract}
Based on this viewpoint, the present study aims at teaching the concept of tissue to the autistic children. In the study, an education environment aided by visual materials was created by using the sense organs peculiar to these children and the effects of learning was put forward. Research group consisted of two autistic children who were aged 12 . Research presented a case study. Qualitative data in the research were obtained by interview, observation and assessment of the students' paintings by the researchers. Interview was carried out by asking five questions to the mothers and visual arts teachers of the students. Paintings of the children were assessed and interpreted in line with the painting assessment criteria developed by the researchers. Data of the observation included the interpretation of the records taken during the practices via video tapes and photographs. According to the interview data obtained in the research, families and visual arts teachers are of the conviction that art activities have positive impacts on autistic children and art lessons are essential. At the end of the observation, it was concluded that teaching the concept of tissue to the autistic children through different techniques and materials was more effective and enabled them to participate in the course willingly. Paintings of students were acclaimed in terms of colour, setting, texture and technique. Results of the research showed once more that a purposeful art education should be included in the programs of special education institutions for the education of autistic children.
\end{abstract}

Key Words: Autism, Art education, Concept of texture

\footnotetext{
${ }^{1}$ The present paper was presented at The Anadolu International Symposium on Arts Education as report.
} 


\section{Introduction}

Individuals acquire all competencies which they require to express themselves and survive in society through education. First of all families, then friends, culture and most importantly educational institutions are responsible for education of individuals. Schools as significant institutions in education of children must maintain a certain adequacy to answer children's needs. Indeed, some of children exhibit differences from others normally developed. Although these children are sometimes found to be talented to the highest degree with their superior-high intelligence, on the contrary sometimes their intelligence is found underdeveloped and that they experience difficulties in certain areas of life. Accordingly, these children require special education. Special education is described by Ataman as "an education which is offered to the children with different and special needs, which enables children with superior characteristics to reach top of their capacities along with their special talents, which prevents disability to turn into an obstacle in their life, and which equips an disabled individual with skills allow them to socialize, to make them independent, productive, self-sufficient individuals" (Ataman, 2003, pp.19).

Amongst the disability types, autism is "severe and complex developmental disorder which can be observed in the first three years of childhood in the forms of limited communication and social skills, limited attention, obsessed and repeating behaviors due to different reasons" (Özbey, 2005, pp. 13). Not only obsessed behaviors or limitations in social communication in children, but also there can be multiple symptoms observed. "Autism is a lifelong issue, even though its severity and symptoms usually continue with decreasing pace. This issue adversely affects a child's social life, communication skills and behaviors. Intensity of the picture occurred and the combination of problematic behaviors are different in every autistic child" (Kayaalp, 2000, pp. 8). The general symptoms of autism, according to Grandin (2005), no speech at all, or abnormal way of talking, failure to establish eye contact, bad temper seizure, 
over reaction to touching, acting like a hearing impaired person, repeater gestures, desire not to be left alone, cold temper, inability to establish social relationship with the family members, and inability to play with toys in as it is supposed to (pp.38). According to Kayaoğlu and Görür (2008), "autistic individuals may present hyperactivity, attention deficit, impulsivity, aggressiveness, self-destruction and in terms of toddlers, behavioral symptoms such as bad temper seizure and moodiness" (pp. 60).

Reasons of autism have been investigated quite a long time; however it is still not clear what the main cause underneath this. Scientists have agreed on a term that there is no single cause instead, it occurs as a result of multiple factors. It can be said that amongst the reasons of autism, psychodynamic and family factors have significant place. "In our contemporary era, autism is linked with organic reasons; and in several researches, the relationship between autism and abnormalities in brain, brain stem, cerebellum, and genetic factors. Although there are numerous genetic findings in the literature, position of the genetic structure in autism is not clear yet" (Sucuoğlu, 2003, pp. 400). It is suggested that incidents which take place during prenatal, birth and after birth periods, biochemical and neurological causes, disorder in dopamine and serotonin systems can be related with the autism. According to Turan (2005), "all symptoms regarding causes of autism indicate brain damage or malfunction in brain" (pp. 95).

Education in autism requires comprehensive and deep knowledge about the subject. In education of a child with autism, educators and families are required to form an education program with multiple aspect after getting acquainting the typical characteristics of the child, his/her needs, talents, likes and dislikes. Wing (2005) stated that some researches presented positive impact of early education in terms of the development position where children with autism can reach (pp.198). 
Amongst the methods employed in treatment of autistic children, treatment with art has a significant place. Art must be one of the important means for emotional expression of these children. Korkmaz (2000) indicates that autistic children are interested in art and painting, even some of them have superior-high talents in these areas and accordingly these talents can be used for their treatment as well (pp.105). Art education is an effective environment in regard to self-expression of children, especially to express their feelings, and in development of material usage and their handcraft. Especially, when stress, boredom and depression among autistic individuals are taken into consideration, it is possible to relieve this depression and to relax by means of art education. Art education aims individuals to gain capability to feel when they touch, to perceive when they hear, and to understand when they see. Another purpose of art education is to allow individuals to create something new, to experience this pleasure at the end of this creation process, and in the meantime, to obtain multi-dimensional perspective.

An autistic child expresses him/herself or learns by means sense organs, especially by touching, hearing and seeing. Application and experiencing are essential factors in learning process of children with autism because these children have severe malfunctions in their motor, cognitive and behavior characteristics. Children with autism have different level of information processing and recalling process. Therefore, their learning process is quite difficult and it takes longer. Another characteristic of these children is their inefficiency in perception of abstract concept. However, they are able to perceive concrete materials that they see. Consequently, if they participate into an activity, efficiency of this learning process will be higher and permanence of that information will be longer in the same extent.

\section{Visual Arts Education for Autistic Children}

Visual Arts education is significant part of education of children with autism. These activities enable to relieve boredom, fear and anxieties inside children, which sometimes cause them to 
have seizure and to relax by means of painting. In their studies, Buyurgan and Buyurgan (2012) stated that "different art activities such as painting, tearing \& gluing and giving shape are applications that proving opportunity to relieve physically and to spend their time happily in terms of mental aspect. Again, children and youth express their senses (joy, fear), desires and expectations" (pp. 11). Moreover, visual arts education is considered as a necessity in term of establishing hand \& eye coordination and developing some motor skills. "Art education supports all sorts of learning formations (cognitive-visual-affective-kinesthetic) because art teaching takes place between teacher and learner (teacher-student) through intentional-meaningful communication and interactions within the framework of predetermined aesthetical activities" (Artut, 2009, pp. 98).

Özbey (2005) suggested several clues regarding preliminary stage of education of children with autism so as to increase efficiency of their education. These clues are casting a model, physical assistance, token, verbal, giving directive, asking question, materials, time, game, reward and punishment (pp. 61-65). These clues can be applied during the visual art activities for children with autism.

According to Kırışoğlu (2009), "representation method is utilized to explain a technique, a skill and a work process. In case a verbal explanation would be insufficient, and a case or technique would not be learnt without seeing practical application, this method is applied. Since learner follow the process with by seeing it and focusing his/her attention over it, learning process gives permanent result" (pp. 106). This method is considered as more important in learning process of children with autism. After the teacher create appropriate learning environment for an autistic child, first, he/she needs to draw and exhibit the concepts or behaviors supposed to be taught to the child so that he/she cast a role model. 
In visual art class, material usage is essentially important and required. Based on the target concept, it will be beneficent to increase efficiency in the classroom through using art materials such as art papers, colorful boards, surplus materials, and visual materials such as computer, power point, and pictures. It is also important employing art in education process of individuals with disabilities. Kınalı (2003) suggested that art materials provide convenience to cretins in using their hands and eyes, and in seeing some facts and in making selection (pp. 259). Children with autism are only able to comprehend concrete concepts. If an abstract concept is to be taught, this teaching process must be supported by means of several materials. That is, it important for children to learn by using all senses of seeing, hearing, tasting, touching, and smelling. Thus, more convenient and persisting learning process can be obtained. Perception and imagination of an autistic child are different than a normal child. Visuality is substantially important for them.

Art activities have come into prominence in learning process of both normal and disabled children because it makes crucial contribution to all development aspects of a child and facilitates learning by providing more comfortable and peaceful environment with full of positive energy (Kınal1, 2003, pp. 257). From this point of view, the present study aims to reveal contribution of art education in learning process of children with autism.

\section{Method}

\section{Research Model}

The research was a case study. Of the "Purposeful Sampling" methods appropriate for qualitative studies, the "Typical Case Sampling" was conducted. According to Yıldırım and Şimşek (2008), "if researcher is in need to introduce a novelty or a new application, amongst a series of condition in which a novelty or a new application exists, the most typical one or several of them are determined to conduct the study on them" (pp. 110). 


\section{Subject Group}

The study group of the research was consisted of twelve year old one female and a male child with autism who receive special education and who are able to use scissors from the Special Education School and Rehabilitation Center for Handicaps under Turkish Armed Forces Health Foundation in the spring semester of 2012-2013 education year. While female student previously received visual arts class and she is interested in this class, the male student has not taken visual art class before however, he took ceramic class once. He is interested in the class but he has hesitation regarding touching the material, and is experiencing trust issue. Both students were diagnosed with autism.

\section{Data Collection Tools}

Qualitative data utilized in the research was collected through observations, interview, and taking photographs of students after sessions.

The application was conducted by means of touching cards developed to teach texture concept, dramatization and power point; then, after students' learning process concerning animals, they were made draw pictures of animals which they prefer.

Observation was conducted under two separate class session to teach texture concept. To increase reliability of the observation process, all application was video-taped and photographs were taken. Video and photograph cameras were handled by an assistant teacher and a visual art teacher.

Researchers organized a questionary consisted of five questions to be answered by students' parents. While visual arts teacher conducted the survey with female student's mother over the phone, an interview was conducted with male student's mother at the rehabilitation center. Survey questions were composed of "closed-end questions" which are applied frequently in 
structured interviews. These fives questions asked parents aim to determine the exact diagnosis of the child, whether has he/she taken visual art class before, if he/she has, how long has he/she attended that class, whether art classes have positive effect on child, and whether the child is interested in that class.

In terms of five questions asked to the visual art teacher, it was aimed to measure whether the student has taken any class before him/her, student's interest to the class, the difference between the student and normal children, whether art activities cause reductions in autistic symptomatic behaviors and their personal opinion about necessity of art classes. Specialists were consulted to provide reliability and validity of survey questions.

\section{Data Analysis}

"Descriptive analysis" was used in analysis of collected data. Quotations from answers given by family and visual arts teacher during interviews were utilized and evaluated comparatively in the "Findings and Conclusions" section of this research.

Notes taken during observations (concerning student's behaviors, mimics, excitements, their questions and hesitations) were utilized and assessed in "Findings and Conclusions" section of the research. Video recordings and photographs taken as a supportive action during observations were used in explanation of students' behavior and reactions.

At the end of the application, students' paintings were assessed by two specialists based on "painting evaluation criterions".

Articles included in "painting evaluation criterions" were presented below:

1) Ability to use the technique correctly,

2) Ability to express the texture,

3) Color usage, 
4) Usage of space,

5) Observations during the application process.

\section{In-Classroom Teaching Activity for Texture Concept in Visual Arts Education}

The teaching process for texture concept which is one of the art design elements to children with autism was summarized below:

From the point of view that children with autism can learn better abstract concepts by touching, seeing, sensing, there were four animals determined. The reasons for choosing these animals were that children might like them and they might see them in their daily life. For these selected animals, several touching cards were prepared by means of fabric parts giving similar sense to their texture so as to give tactual characteristic.

Prior the activity, a power point presentation was prepared for these four animals (horse, rabbit, sheep and dolphin) as their names written and their textures were explained underneath the slides.

Moreover, there were four tin boxes with relevant animal names on them, which were prepared and small squares appropriate to animal textures sawn on them to make the activity more attractive, interesting and as to repeat texture concept.

Firstly, children were allowed to touch their chair and desk where perform their activities so that they comprehend the texture concept briefly. Then, children watched power point presentation. After presentation of each introduced animal, the relevant texture card was given to the children then they were asked to touch; simultaneously, explanatory text under the slide (rabbit has soft fur) was read aloud while they are seeing the structure of their texture on the presentation. 
After completing this process, matching-up game was played. That is, children were asked to find out the right relevant animal after letting them to touch corresponding fabric piece. Thus, after the power point presentation and touching cards, children obtain chance to repeat the concept through playing an entertaining matching-up game and accordingly it is ensured that concepts are taught permanently.

Afterwards, students were asked about which of these four animals they liked most; and they were requested to draw the animal which they selected on paper in $35 \times 50 \mathrm{~cm}$ drawing paper by means of a marker pen in any color they might prefer. In the activity conducted with the male student, since student thought that he could not draw that animal and he has not received a visual arts class yet, the researcher first draw the animal by herself so that she could be role model. Additionally, a dolphin picture from one of the colored books which explain animal drawings in the classroom was presented to the student and the student was given directives during following steps in the book to let him draw the picture.

On the other hand since female student has taken visual arts class before, she performed drawing conveniently according to directions. During drawing period, relevant directions were given based on geometric structure of the animal so that children can complete the drawing. For instance, as belly of a rabbit is circular, the student was instructed to draw a circle.

After the drawing was completed, fabric parts which were same with the ones used in other stages, appropriate four types of cords, beads and buttons were introduced to the student in a sequence, and the student was asked to fill out the animal that he/she drew with these materials.

Along with the application, both students were assisted physically (e.g. holding the scissor together, assisting in gluing and sticking the fabric onto the relevant place). After students are 
finished with cut \& paste stage, they were asked to paint the rest of the empty spaces on the picture with pastel e.g. sea, grass, and sun. Hence, the study was completed and at the end of the application photograph of the student was taken with his/her drawing.

The whole process was recorded through video camera and photo camera. Furthermore, it was paid attention to use the same animal pictures and fabric pieces in every stage by taking the fact that children with autism learn hardly and forget easily into consideration.

\section{Findings And Conclusions}

In this section, interviews with the teachers and parents of children with autism were included, then their paintings assessed and evaluated.

When responses of students' parents to the survey questions were considered, the questions of "How old your child was when he/she diagnosed with autism?" and "What is the exact diagnosis of your child?" were answered by the mother of the male student as "when he was 6, he was diagnosed with autism + Pervasive Developmental Disorder"; and answered by the mother of the female student as "when she was 5, and the exact diagnosis was autism". Both students were almost diagnosed with autism at the same age. The question of "for how long your child has been receiving special education?" was answered by mother of male student as "7 years"; and answered by the mother of female student as "6 years". Both students have been receiving education for almost same period of time. The question of "Has your child taken painting /ceramic class before?" was answered by mother of the male student as "No"; by mother of the female student was answered as "She has taken art education before". the female student shows more interest to art classes such as painting/ceramic compared to her peers with autism, and she is more successful at drawing and she continues to take art classes. On the other hand, male student has taken a ceramic class once, and there is no any other art related class beside this. It is understood that he is interested in art, but it was not found 
necessary to take art classes since he experience trust issue with touching art materials. When the children's interest toward art classes such as painting/ceramic was questioned, the mother of the male student expressed her wish about his son to take art class by giving an answer as "He exhibits attention when it is presented"; the mother of the female student answered as "Yes". It was understood that both students are interested in having art classes such as painting/ceramic. Regarding the question of "Is there any positive effects of art classes such as painting/ceramic on your child? (in their social relationships, motor skills and behaviors)", the mother of the male student answered as "There is positive effect"; the mother of the female student answered as "Yes, I believe it make significant contribution to development of abstract concepts, self-expression, skill to play game and communication; additionally, it makes positive contribution to his self-confidence". These answers expose that parents view art classes from a positive perspective.

In the interview with the visual art class, regarding the question of "How long your student has been taken painting/ceramic class from you?", the teacher answered for the female student as "She has been taken course from me for about 2 years; since October 2011"; for the male student as "Only once he took a ceramic course". Regarding the question of "Do your students exhibit interest toward art classes such as painting/ceramic?", the teacher answered for the female student as "Yes, she is interested in"; and for the male student as "He had an interest but he did not have self-confidence about it; he was presenting hesitation about touching materials (mud etc.). He did not want to use the material. We tried to make ceramic painting, and he was more interested in ceramic painting". Regarding the question of "Were these classes efficient in reduction of behaviors related with autism?", the teacher answered for the female student as "Yes, there has been reduction in problematic behaviors by means of art activities. I have observed positive feedbacks concerning her ability to focusing her attention, a development in her self-expression ability and in self-confidence"; and answered 
for the male student as "Since I did not make course with him, I did not have chance to work with him and to make observation". Regarding the question of "Is there any difference between drawings of your student and normally developed children?", the teacher answered for the female student as "Yes, there are. As I have observed in most of the normally developed children, they are able to perform the work as they are given subject and the required technique, but when my student is only given subject and required technique, he/she is not able to perform any work; their development in terms of art is way behind their peers and their anxiety about failure before starting the work is too high"; for the male student as "Yes there is, he is way behind his peers; he does not want to use materials, he is not able to draw (he is able to make drawing with physical help or when someone act as a model)". It was understood that both students were different from their normally developed peers; and that there is significant difference between them in terms of linear development, accurate application of given technique, and material usage. Regarding the question of "Do you think do children with autism need to receive art education classes?", the answer given for both students was that "Yes, they certainly do because they either receive education at special education schools for disabled children or at normal schools as an inclusive student. In special schools, there are classes held according to the self-care skills and special education curriculums which do not include art classes or any classes that can be enjoyed by these children with autism. Therefore I think these classes are needed. When they participate in education as an inclusive student, but in the classroom the teacher takes care all students equally in general so the education is not given by considering special needs of these inclusive students. Consequently, I think it is very important for them to receive art education".

At the end of the interview with the visual art teacher, it was stated that "the art development of the female student was higher than the other students diagnosed with autism; and she 
exhibit more successful results by using different techniques and materials with her interest toward the class"; in addition, it was stated that "there has been evident decrease in her negative autistic behaviors with the help of art activities performed along with two years". On the other hand, regarding the male student, "due to the issues that he experienced in the ceramic class, he has not been taken into any art class and therefore his development in art area lagged behind his normally developed peers and others diagnosed with autism". Additionally, it was stated that "since he has not taken visual art class, it was not known that whether the art class has positive effect on his autistic behaviors".

According to the observations of the researcher concerning art activities performed in two separate classes during the applications, it was determined that the female student came 15 minutes earlier to the classroom; and she was excited about starting to the activity. As soon she entered into the class, she paid attention to the course materials; she was curious about what she can do with those materials in the class; especially she was interested in power point presentation left open on the desk and tried to play with the computer. Then, visual arts teacher came to the classroom and explained her that she will experience a good activity with the researcher teacher. The female student watched the power point presentation with a great interest; she was amazed with the cards that she was asked to touch and did not let them taken away. She touched with great interest and repeated their characteristics a laud. During the game, she put fabric parts into the relevant boxes quickly with no any hesitation. When the drawing section commenced, she stated that her most favorite animal was rabbit and started to draw this animal. However, when she hold up the pencil she was surprised and said "how am I going to draw now, I do not know, but I cannot draw" and hesitated for a while. Upon support of the researcher and visual arts teacher as "you can do, look, its belly is circle, now draw a large circle; and look, its ears are triangle, its tail is circle"; as codes of geometric shapes were given to the student, she was assisted to draw a rabbit shape on a paper. During 
drawing process, she was successful at drawing a rabbit shape with no any outside help. Then, when she was asked that which fabric she wants to use to cover her rabbit; and she picked the right fabric type with feathery and started to cut this right away. She especially liked the feathery fabric and sometimes she patted it and dabbed it onto her face to try to feel its texture. While cutting it with scissor, she experienced some problems; when she was confused, sometimes researcher cut the fabric and sometimes researcher and the student cut it together and completed the cut $\&$ paste stage. During gluing stage, when feathery stack on her hands, she hesitated and asked from the researcher to clean her hands. Again, when she confused during gluing stage, she asked for help from the researcher to glue the fabric parts on the picture. The female student was requested to paint around the rabbit picture after she completed the cut $\&$ paste stage. While female student was painting her picture, the visual arts teacher said "we drew a rabbit picture with you before; what can we do around the rabbit, for instance what does it eat?" The student's answer was that "rabbit eats carrot, I can make a carrot" and she said "it eats grass too" and she drew a large carrot and grass shapes additionally and completed the picture by painting all paper with no any empty spot on it. She made the nose with a button; and made its whiskers with cord after cutting and gluing them appropriately. Only at the last stage, the visual arts teacher assisted her to complete painting while she was making edges of the paper and while she was painting the sky. During the whole class, her interest continued without any disruption with the same pace, enthusiasm and joy; at the end of the class, she posed with her painting and expressed her happiness.

On the other hand, the male student was brought to the visual arts workshop by the researcher and classroom teacher. As the student came to the workshop and sat his seat right away. When he saw the materials on the table he was excited and especially he started to play with the computer. For the first five minutes, he expressed his hesitation and shortly he started to pay his attention to the materials on the table, and asked what he would do with them. During 
the course, the classroom teacher sat at the corner and the activity was videotaped by the assistant teacher. At the beginning of the class, the power point presentation attracted his attention and he started read explanatory texts under each animal loudly. When he saw the study cards that he needs to touch, he get excited and touched them frequently and talked about what their texture looked like. In matching up game, he placed fabric parts quickly into the relevant boxes without any hesitation. During the application, when the researcher asked about that "have you visited zoo before?", he replied that "I went, there were horse, and I rode on a horse". When her progressed to the drawing stage, he replied about the animal that he liked most that "I can only like dolphin, I only draw dolphin" and he started to draw dolphin picture. However, when he picked up marker pen, he expressed that he cannot do this by saying "I cannot draw, I cannot do, how am I going to draw?" and he was hesitated. The researcher picked another piece of paper and drew a dolphin picture to be a role model for him. The researcher used a book which was showing animal drawings in stage by stage and which was already in the classroom. The teacher showed drawing stages of a dolphin from this book and allowed the student to draw a dolphin. By assisting him through directives, he completed the picture and the student was asked about that what type of fabric he wants to use to cover the drawing. The student picked up the appropriate fabric piece with no any hesitation and started to cut it. While he was using scissor, he experienced problem. The researcher assisted to the student by sometimes holding his hands and sometimes by cutting the fabric. During gluing stage, the student asked for help from the researcher by saying "stick it to here". Then, the male student was requested to paint around the dolphin picture. He said that "dolphins live in the sea, look there are water sprinkles on it" and painted his picture with blue and did not neglect to put water sprinkles on it. On eye of the dolphin, he glued a bead that he liked. During painting, the student did not get assistance at all. The male student was excited and willing along with all activity. Sometime he was so excited that the classroom 
teacher invited his mother and other teachers into the classroom to let them witness his excitement and happiness. The male student did not give the painting he made to the researcher, he took it away with him; and he said that "I will put this on my wall; I do not give it away". At the end of the course, he posed with his painting and their photograph was taken.

\section{Results And Suggestions}

When animal pictures, and cutting \& pasting processes performed by the students with autism were taken into consideration, it was observed that they were experiencing difficulties in using scissors and jammed in cutting process due to malfunctions in their motor skills caused by their disease. However, although students experienced difficulties in using scissors, it was observed that fabric parts were cut and glued according to the drawing; they made painting successfully similar to their normal peers; they expressed the spatial sense in their works; they perceived the texture concept which is desired to be gained more easily through this activity; and they performed realistic painting appropriately by establishing connection between color and nature.

It was seen that both of the two children's mothers are supportive and willing in terms of their children to be participated art activities; and the mothers thought that art activities play positive role in learning process and in mental relaxation of their children.

As a result of the research, the significance of art education and especially usage of visual materials in education of children with autism were exhibited once more; and it was observed that within the process of developed art education activity in teaching of texture concept, they make positive contribution; and especially, they are effective in development of their behavior and motor skills; and they allow students to experience success feeling by giving them selfconfidence feeling; and students are quite happy and peaceful in the art environment where they work ambitiously and with excitement. 
- Administrations of the special education schools for children with disability, visual arts teachers, classroom teachers and parents of children with autism must be more aware about significance of art education in their children's education and relaxation.

- Different art activities must be developed and used in education of these children with autism in special education schools.

- In learning process of children with autism, attractive material, various art techniques must be utilized. 
Appendix 1: Application Photographs
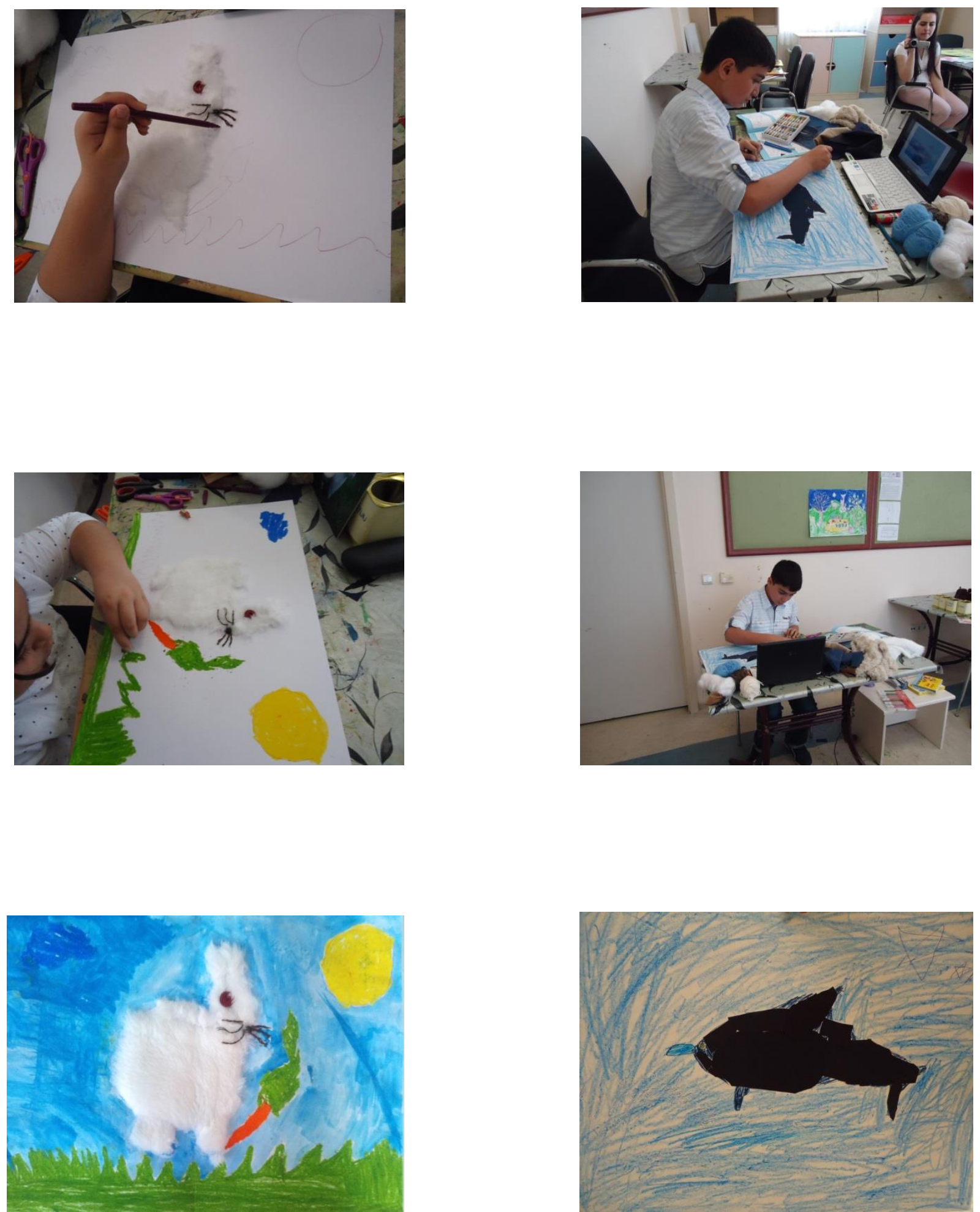

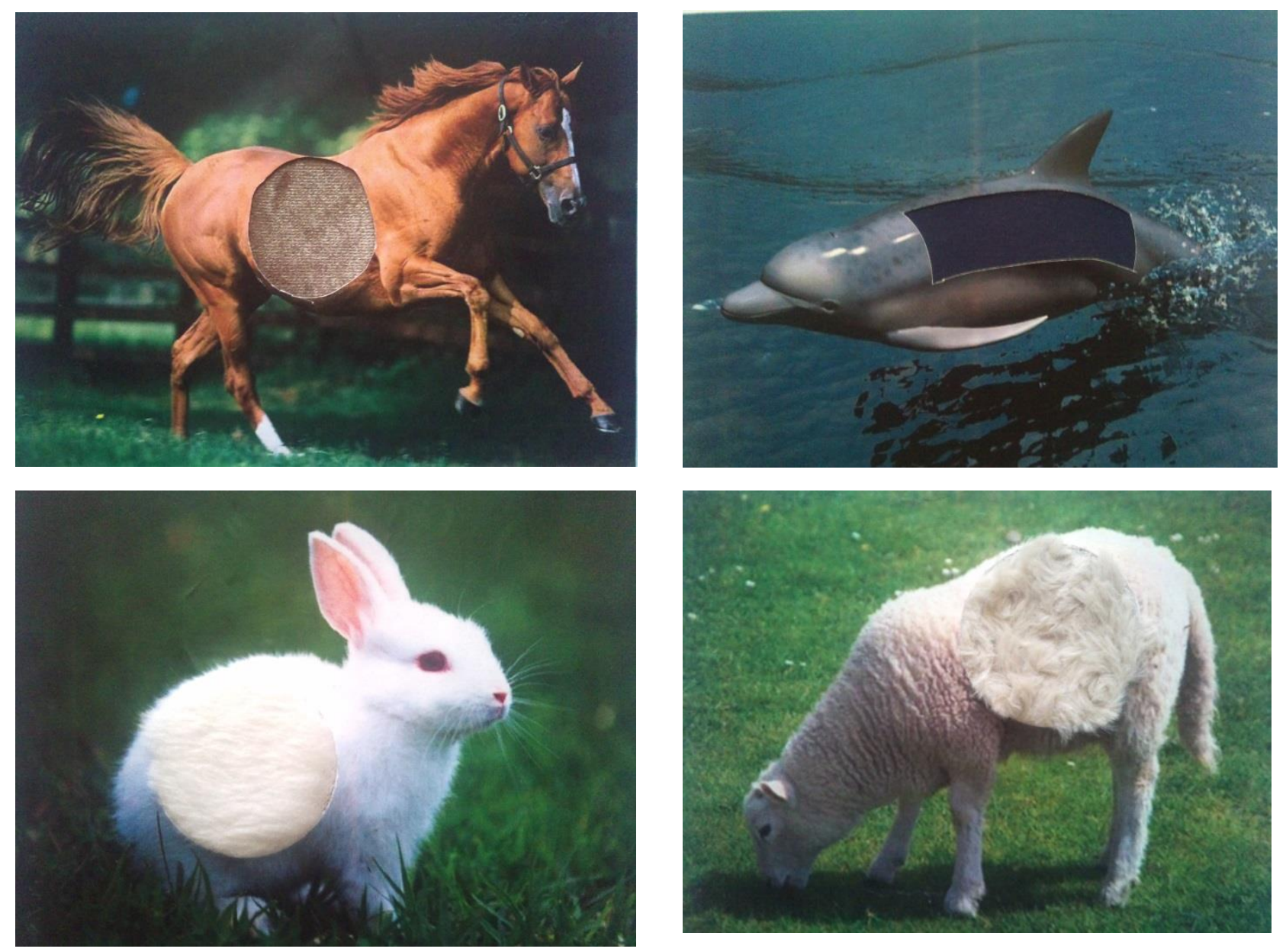

Touching Cards
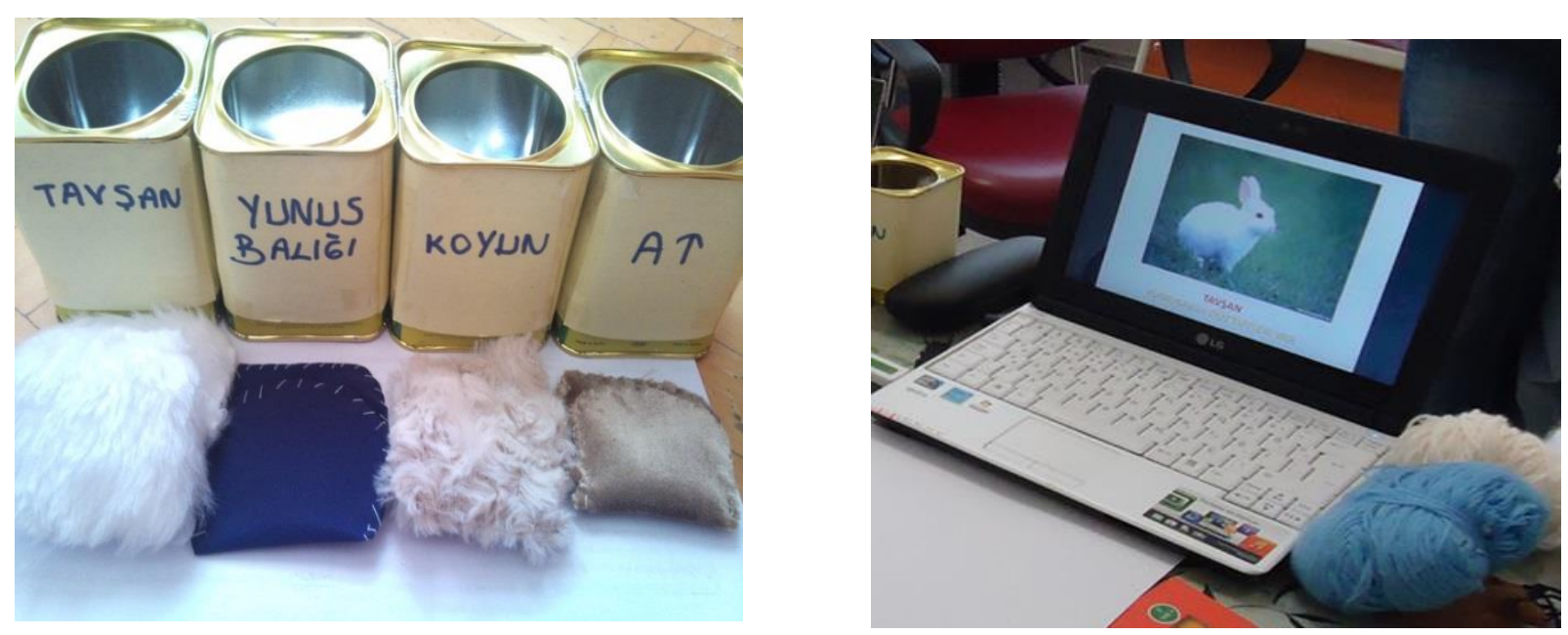

Matching-Up Game

PowerPoint Presentation 


\section{Reference}

Ataman, A. (2003). Children in Need Special Care and Introduction to Special Education,

Ataman, A. (Editor). Children in Need Special Care and Special Education. First Edition. Ankara: Gündüz Eğitim ve Yayıncılık, pp.19.

Artut, K. (2009). Art Education Hypothesis and Methods. (6 ${ }^{\text {th }}$ Edition). Ankara: An1 Press. Buyurgan, S. and Buyurgan, U. (2012). Art Education and Teaching. ( ${ }^{\text {rd }}$ Edition). Ankara: Pegem A Press.

Grandin, T. (2005). Thinking with pictures. (Translated by M.C.İftar). İstanbul: Doğan Press. (The original edition was issued under the name of "..........").

Kayaalp, İ.V. (2000). Education of Children with SOS Autism and Communication Problem. ( $1^{\text {st }}$ Edition). İstanbul: Evrim Press.

Kayaoğlu, N. and Görür, Ö. (2008). How do children with autism learn? (1 ${ }^{\text {st }}$ Edition). Ankara: Eros Press.

Korkmaz, B. (2000). What is the Rainman Autism?. (1 ${ }^{\text {st }}$ Edition). İstanbul: Doğan Press.

Kınalı, G. (2003). Children with unusual development. Kulaksızoğlu, A. (Editor). Physical Art-Music Education for Mentally Challenged Children. Second Edition. İstanbul: Epsilon Press. pp. 257-259.

Kırışoğlu, O.T. (2009). Art Culture Creativity. (1 ${ }^{\text {st }}$ Edition). Ankara: Pegem A Press.

Özbey, Ç. (2005). Autism and education of children with autism: a journey to the land of loneliness. ( $1^{\text {st }}$ Edition). İstanbul: İnk1lap Press. 
Sucuoğlu, B. (2003). Children Need Special Care and Introduction to Special Education.,

Ataman, A. (Editor). Autism and Children with Autism. First Edition. Anakara: Gündüz Eğitim ve Yayıncılık, pp.400.

Turan, A. (2005). Children Who Speak Language of Love. (3 ${ }^{\text {rd }}$ Edition). İstanbul: Sistem Press.

Wing, L. (2005). Hand Book of Autism. (Translated by. Semra Kunt). İstanbul: Doğan Press. (Original edition was issued in 1996).

Yildırım, A. and Șimșek, H. (2008). Qualitative Research Methods in Social Science. $\left(6^{\text {th }}\right.$ Edition). Ankara: Seçkin Press. 